1 A. C. Kurtz, J. biol. Chemistry 122, 477 [1937-38].

2 A. C. Kurtz, J. biol. Chemistry 180, 1253 [1949].

3 L. M. Volshtein u. L. S. Anokhova, Russ. J. Inorg. 4, 142,781 [1959].

4 D. A. Buckingham, L. G. Marzilli u. A. M. Sargeson, J. Amer. chem. Soc. 89, 2772 [1967].

5 J. P. Collman u. E. Kimura, J. Amer. chem. Soc. 89, 6096 [1967].

6 a) H. Ley u. K. Ficken, Chem. Ber. 45, 377 [1912] ; b) A. A. Grinberg u. B. V. Ptitsyn, J. prakt. Chem. [2] 136, 143 [1933] ; c) F. W. Pinkard. E. SharratT, W. WardLAw u. E. G. Cox, J. chem. Soc. [London] 1934, 1012.

7 A. A. Grinberg u. L. M. Volshtein, Izv. Akad. Nauk. SSSR, Ser. Khim. 4, 885 [1937].

8 L. M. Volshtein u. G. D. ZegZhda, Russ. J. Inorg. Chem. 7, 5 [1962].
9 L. M. Volshtein u. T. R. Lastushrina, Russ. J. Inorg. Chem. 14, 246 [1969].

10 G. WalliN, Öfvers. Akad. Stockholm 49, 21 [1892].

11 J. A. Kieft u. K. NaKamoto, J. inorg. nucl. Chem. 29, 2561 [1967].

12 M. P. Springer u. C. Curran, Inorg. Chem. 2, 1270 [1963].

13 L. M. Volshtein u. G. G. Motyagina, Russ. J. Inorg. Chem. 10, 721 [1965].

14 a) J. C. Sheehan u. G. P. Hess, J. Amer. chem. Soc. 77, 1067 [1955] ; b) J. C. Sheehan, M. Goodman u. G. P. Hess, J. Amer. chem. Soc. 78, 1367 [1956].

15 vgl. H. G. Khorana, Chem. and Ind. 1955, 1087.

16 E. Fischer, Chem. Ber. 34, 444 [1901].

17 M. Viscontini, C. R. Séances Acad. Sci. 221, 445 [1945].

\title{
Coordination Polymers of Some Trivalent and Tetravalent Metals
}

\author{
U. B. SAXena, A. K. RAI, and R. C. Mehrotra \\ Chemical Laboratories, Rajasthan University, Jaipur (India) \\ (Z. Naturforsch. 27 b, 1145-1148 [1972] ; received April 4/May 17, 1972)
}

\begin{abstract}
The reactions of ethoxides and isopropoxides of aluminium and titanium with bis (acetoacetates) in various molar ratios have been carried out. In all the cases, the treatment in the molar ratio $1: 0.5$ and $1: 1.0$ liberated one and two moles of alcohol respectively. The isopropoxy groups could be fully replaced only in the case of aluminium, when the reactions was carried out in higher molar ratio (1 : 1.5). However, even with excess of the ligand, the replacement of the fourth molecule of alcohol in case of titanium could not be accomplished.
\end{abstract}

In the reactions of titanium alkoxides with bis (acetoacetates) ${ }^{1}$ in molar ratio $1: 0.5$, only one mole of alcohol is liberated in each case and the product corresponded in analyses to $\mathrm{Ti}_{2}(\mathrm{OR})_{6}$ bis (acetoacetate). In view of the interesting results obtained in this investigation, it was considered of interest to extend the study of the reactions of bis (acetoacetates) with the alkoxides of aluminium and titanium.

The present communication deals with the reactions of alkoxides of aluminium and titanium with bis(acetoacetates) in various molar ratios. These bis(acetoacetates) can be represented by the following structure:<smiles>CC(O)CCOC(=O)C(C)O</smiles>

(where $n=2,4$ and 5).

Requests for reprints should be sent to Dr. R. C. MEHRotra, Department of Chemistry, University of Rajasthan, Jaipur-4 (India).
Reactions of ethoxides and isopropoxides of aluminium and titanium with bis (acetoacetates) were carried out in benzene in molar ratios $1: 0.5,1: 1$, $1: 1.5$ and $1: 2$ under refluxing conditions. The progress of the reaction was followed by estimating the amount of ethanol or isopropanol fractionated out azeotropically with benzene. Products were isolated after removing volatile fractions under reduced pressure. The reactions in the molar ratio 1 : 0.5 liberate one mole of alcohol per mole of alkoxide taken in all the cases:

$$
2 \mathrm{M}(\mathrm{OR})_{n}+\mathrm{AH}_{2} \rightarrow \mathrm{M}_{2}(\mathrm{OR})_{2 n-2}(\mathrm{~A})+2 \mathrm{ROH}
$$

(Where $\mathrm{M}=\mathrm{Al}$ or $\mathrm{Ti} ; \mathrm{AH}_{2}=$ bis(acetoacetates), $\mathrm{R}=\mathrm{C}_{2} \mathrm{H}_{5}$ or $\mathrm{C}_{3} \mathrm{H}_{7}{ }^{\mathrm{i}}$ and $\mathrm{n}=3$ or 4 .)

In the case of aluminium, a cream coloured precipitate separates out during the reaction; this is found to be insoluble in common organic solvents and decomposes at about $200{ }^{\circ} \mathrm{C}$ when heated under reduced pressure with the elimination of corresponding alkoxides. The insolubility of these derivatives may be ascribed to the presence of active functional groups at the end which increases the probability of further polymerisation. 
When the reactions were carried out in $1: 1$ molar ratio in benzene, two moles of alcohol are liberated out under similar experimental conditions:

$$
\mathrm{M}(\mathrm{OR})_{n}+\mathrm{AH}_{2} \rightarrow \mathrm{M}(\mathrm{OR})_{n-2}(\mathrm{~A})+2 \mathrm{ROH}
$$

(where $\mathrm{M}=\mathrm{Al}$ and $\mathrm{Ti} ; n=3$ or 4 and $\mathrm{R}=\mathrm{C}_{2} \mathrm{H}_{5}$ or $\mathrm{C}_{3} \mathrm{H}_{7}^{\mathrm{i}}$ ).

In the case of aluminium, colourless insoluble products decomposing at about $200{ }^{\circ} \mathrm{C}$ under reduced pressure were obtained.

In the case of titanium, yellow orange products decomposing at about $200{ }^{\circ} \mathrm{C}$ under reduced pressure were obtained. The products are initially soluble, but became less soluble as the solvent is distilled out under reduced pressure. The poor solubility after the removal of the solvent under reduced pressure may be ascribed to the gradual formation of polymeric products. Their molecular weight determination in the initial stages, carried out ebullioscopically in benzene showed them to be tetrameric in nature.

When the reactions were carried out in the molar ratio $1: 1.5$, three moles of alcohol were liberated in both the cases:

$$
2 \mathrm{M}(\mathrm{OR})_{n}+3 \mathrm{AH}_{2} \rightarrow \mathrm{M}_{2}(\mathrm{OR})_{n-3}(\mathrm{~A})_{3}+6 \mathrm{ROH}
$$

(where $\mathrm{M}=\mathrm{Al}$ or $\mathrm{Ti} ; n=3$ or 4 and $\mathrm{R}=\mathrm{C}_{2} \mathrm{H}_{5}$ or $\mathrm{C}_{3} \mathrm{H}_{7}{ }^{\mathrm{i}}$ ).

The reactions in the case of aluminium were quite facile and would be completed within five hours with the formation of an insoluble product.
However, in the case of titanium the reactions proceeded very slowly and the third alkoxy group could only be removed after sixteen hours of refluxing. The compounds are coloured and insoluble in benzene. Although attempts were made to determine their molecular weights in chloroform, reliable results could not be obtained due to a very limited solubility in this solvent also. The formation of tris-bis(acetoacetate) derivatives in the case of titanium is of interest when it is compared with the reactions of titanium alkoxides with $\beta$-diketones and $\beta$-ketoesters ${ }^{3}$ where monomeric $\mathrm{Ti}(\mathrm{OR})_{2}(\mathrm{~L})_{2}$ is obtained (where $\mathrm{L}=\beta$-diketone or $\beta$-ketoester). Further replacement of alkoxy group is not possible and ultimately oxy products were obtained when attempts were made to push the reaction further.

In the present investigations, the replacement of third alkoxy group indicates the possibility of attainment of higher coordination number (seven) by titanium if all the possible coordinating groups are actually utilised fully. The seven coordination state of titanium has been reported by MUETTERTIES and coworkers ${ }^{4}$ in the derivatives of the type $\mathrm{T}_{3} \mathrm{TiCl}$ (where $\mathrm{T}=$ propolene) .

When the reactions were carried out in the molar ratio $1: 2$ or $1:>2$, the fourth alkoxy group in the case of titanium could not be replaced even after prolonged refluxing due to steric hindrance. Thus, it appears that the reaction in the above molar ratios yielded, after washing the products re-

\begin{tabular}{|c|c|c|c|c|c|c|c|}
\hline S. & Reactants in $\mathrm{g}$ & $\begin{array}{l}\text { Molar } \\
\text { ratio }\end{array}$ & $\begin{array}{l}\text { Product, state } \\
\text { and yield in } g\end{array}$ & $\begin{array}{l}\text { Alcohol } \\
\text { in the } \\
\text { azeotrope } \\
\text { (g) } \\
\text { Found } \\
\text { (Calcd) }\end{array}$ & $\begin{array}{l}\text { Alumini- } \\
\text { um }[\%]\end{array}$ & $\begin{array}{l}\text { Carbon } \\
{[\%]}\end{array}$ & $\begin{array}{l}\text { Hydrogen } \\
{[\%]} \\
\text { Found } \\
\text { (Calcd) }\end{array}$ \\
\hline 1. & $\begin{array}{l}\mathrm{Al}\left(\mathrm{OPr}^{\mathrm{i}}\right)_{3}, 3.15 \\
\text { Ethylene bis(acetoacetate) } \\
\mathrm{C}_{10} \mathrm{H}_{14} \mathrm{O}_{6}, 1.77\end{array}$ & $2: 1$ & $\begin{array}{l}\mathrm{Al}_{2}\left(\mathrm{OPr}^{\mathrm{i}}\right)_{4}\left(\mathrm{C}_{10} \mathrm{H}_{12} \mathrm{O}_{6}\right) \\
\text { Light yellow solid, } 4.0\end{array}$ & $\begin{array}{c}0.9 \\
(0.9)\end{array}$ & $\begin{array}{c}10.2 \\
(10.4)\end{array}$ & $\overline{-}$ & - \\
\hline 2. & $\begin{array}{l}\mathrm{Al}\left(\mathrm{OPr}^{\mathrm{i}}\right)_{3}, 3.0 \\
\text { Ethylene bis(acetoacetate), } 3.38\end{array}$ & $1: 1$ & $\begin{array}{l}\mathrm{Al}\left(\mathrm{OPr}^{\mathrm{i}}\right)\left(\mathrm{C}_{10} \mathrm{H}_{12} \mathrm{O}_{6}\right) \\
\text { Light yellow solid, } 4.69\end{array}$ & $\begin{array}{c}1.7 \\
(1.8)\end{array}$ & $\begin{array}{l}8.7 \\
(8.6)\end{array}$ & $\begin{array}{c}48.75 \\
(49.68)\end{array}$ & $\begin{array}{c}6.05 \\
(6.05)\end{array}$ \\
\hline 3. & $\begin{array}{l}\mathrm{Al}\left(\mathrm{OPr}^{\mathrm{i}}\right)_{3}, 3.78 \\
\text { Ethylene bis(acetoacetate), } 6.40\end{array}$ & $2: 3$ & $\begin{array}{l}\mathrm{Al}_{2}\left(\mathrm{C}_{10} \mathrm{H}_{12} \mathrm{O}_{6}\right)_{3} \\
\text { Light yellow solid, } 6.4\end{array}$ & $\begin{array}{l}3.3 \\
(3.35)\end{array}$ & $\begin{array}{l}7.2 \\
(7.3)\end{array}$ & $\begin{array}{c}48.22 \\
(48.78)\end{array}$ & $\begin{array}{c}4.48 \\
(4.87)\end{array}$ \\
\hline 4. & $\begin{array}{l}\mathrm{Al}\left(\mathrm{OPr}^{\mathrm{i}}\right)_{3}, 4.4 \\
\text { Tetramethylene bis(acetoacetate) } \\
\mathrm{C}_{12} \mathrm{H}_{18} \mathrm{O}_{6}, 2.84\end{array}$ & $2: 1$ & $\begin{array}{l}\mathrm{Al}_{2}\left(\mathrm{OPr}^{\mathrm{i}}\right)_{4}\left(\mathrm{C}_{12} \mathrm{H}_{16} \mathrm{O}_{6}\right) \\
\text { Light yellow solid, } 6.15\end{array}$ & $\begin{array}{l}1.3 \\
(1.3)\end{array}$ & $\begin{array}{l}9.7 \\
(9.9)\end{array}$ & - & - \\
\hline 5. & $\begin{array}{l}\mathrm{Al}\left(\mathrm{OPr}^{\mathrm{i}}\right)_{3}, 2.94 \\
\text { Tetramethylene bis } \\
\text { (acetoacetate), } 3.72\end{array}$ & $1: 1$ & $\begin{array}{l}\mathrm{Al}\left(\mathrm{OPr}^{\mathrm{i}}\right)\left(\mathrm{C}_{12} \mathrm{H}_{16} \mathrm{O}_{6}\right) \\
\text { Light yellow solid, } 5.0\end{array}$ & $\begin{array}{l}1.7 \\
(1.7)\end{array}$ & $\begin{array}{l}8.0 \\
(7.9)\end{array}$ & $\begin{array}{c}51.52 \\
(52.63)\end{array}$ & $\begin{array}{c}6.72 \\
(6.60)\end{array}$ \\
\hline 6. & $\begin{array}{l}\mathrm{Al}\left(\mathrm{OPr}^{\mathrm{i}}\right)_{3}, 2.33 \\
\text { Tetramethylene bis } \\
\text { (acetoacetate), } 4.42\end{array}$ & $2: 3$ & $\begin{array}{l}\mathrm{Al}_{2}\left(\mathrm{C}_{12} \mathrm{H}_{16} \mathrm{O}_{6}\right)_{3} \\
\text { Light yellow solid, } 4.7\end{array}$ & $\begin{array}{l}2.0 \\
(2.1)\end{array}$ & $\begin{array}{l}6.4 \\
(6.6)\end{array}$ & $\begin{array}{c}51.55 \\
(52.55)\end{array}$ & $\begin{array}{c}5.49 \\
(5.84)\end{array}$ \\
\hline
\end{tabular}

Table I. Reactions of $\mathrm{Al}\left(\mathrm{OPr}^{\mathrm{i}}\right)_{3}$ with $\mathrm{Bis}$ (acetoacetates) 
Table II. Reactions of $\mathrm{Ti}(\mathrm{OR})_{4}$ with Bis (acetoacetates).

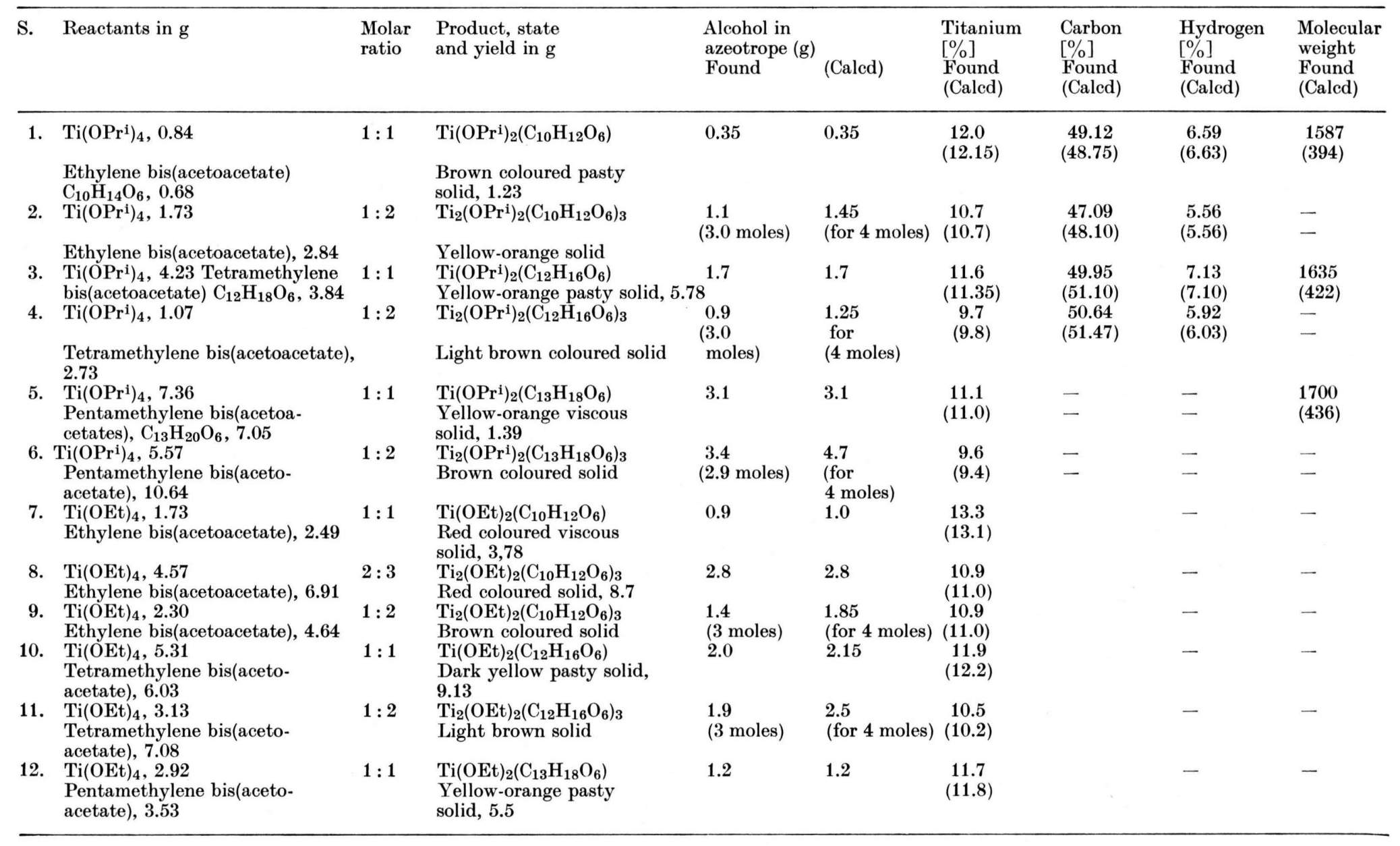


peatedly with benzene, derivatives similar to those obtained in the molar ratio $1: 1.5$. The results are summarised in Tables I and II.

\section{Experimental}

Moisture was excluded and all glass interchangeable standards joints were used. Benzene was dried by usual procedures. Aluminium (2) and titanium alkoxides (3) were prepared as described.

Molecular weights were determined by a Gallenkamp ebulliometer having a sensitive thermistor in benzene.

Analyses: Aluminium and titanium were estimated as oxinate and oxide respectively. Alcohols in the azeotrope were estimated by oxidation with $N$-dichromate in $12.5 \%$ sulphuric acid ${ }^{5}$. The percentage carbon and hydrogen in case of few derivatives are determined in the laboratories of Commonwealth Scientific and Industrial Research organisation (C. S. I. R. O.) Melbourn, Australia.

\section{Reactions}

Reactions of Aluminium isopropoxide with ethylene bis(acetoacetate) in molar ratio $1: 0.5$

To a solution of aluminium isopropoxid $(3.15 \mathrm{~g})$ in benzene $(50 \mathrm{~g})$ was added ethylene bis(aceto-

1 U. B. Saxena, A. K. Rai, and R. C. Mehrotra, Ind. J. Chem. 5, 368 [1967].

2 R. C. Mehrotra, J. Indian chem. Soc. 30, 585 [1953].

3 D. M. PurI, Ph. D. Thesis, Gorakhpur University, Gorakhpur (India) 1962. acetate) $(1.77 \mathrm{~g})$. The reaction mixture became light yellow. It was then refluxed under a fractionating column at $120-125^{\circ} \mathrm{C}$ for about two hours. The isopropanol liberated in the reaction was removed completely by fractionation of the azeotrope between $72-80^{\circ} \mathrm{C}$. A light yellow solid settled down in the bottom. The product was filtered and was dried under reduced pressure at $40^{\circ} \mathrm{C} /$ $0.5 \mathrm{~mm}$ to yield a light yellow solid $(4.0 \mathrm{~g})$, insoluble in benzene and other common organic solvents. Found: Isopropanol in the azeotrope, $0.90 \mathrm{~g}$ (two moles require $0.92 \mathrm{~g}$ ).

Found: $\mathrm{Al}, 10.19 \%$. Calc. for $\mathrm{Al}_{2}\left(\mathrm{OPr}_{4}^{\mathrm{i}}\right)_{4}\left(\mathrm{C}_{10} \mathrm{H}_{12} \mathrm{O}_{6}\right)$ : $\mathrm{Al}, 10.38 \%$.

The general method of synthesis was the same in every case; hence the other derivatives of aluminium and titanium are summarised in Tables I and II respectively.

One of us (U. B. S.) thanks the Council of Scientific and Industrial Research, New Delhi, for a Junior Research Fellowship.

4 E. L. Muetterties and C. M. Wright, J. Amer. chem. Soc. 87, 4706 [1965].

5 D. C. Bradley, F. M. Abdel-El Halim, and W. Wardlaw, J. chem. Soc. [London] 1950, 3450 . 